\title{
WOKÓŁ WYWIADU Z KAZIMIERZEM BRANDYSEM
}

\author{
Włodzimierz PRÓCHNICKI (Uniwersytet Jagielloński)
}

Historia wywiadu, udzielonego przez pisarza w 1989 roku paryskiemu Radiu „Solidarność" ma swoją epizodyczną prehistorię. Jedynie częściowo wiąże się ona z osobą autora Nierzeczywistości, dla utrwalenia jednak pragnę ją przytoczyć.

Z początkiem lat 80., w 1983, może rok później trafiłem do Ireny Krzywickiej. Od ćwierć wieku jest ona ikoną polskiego feminizmu, głównie za sprawą publikacji wspomnień (Wyznania gorszycielki) spisanych już na obczyźnie. Wtedy była postacią nieobecną w krajowym życiu literackim. Nie weszła też, chyba głównie z powodu pokoleniowego dystansu i problemów prywatnych, w nurt literatury emigracyjnej. W historii literatury dwudziestolecia pojawiała się jako autorka prozatorskich i publicystycznych tekstów, walcząca o prawa kobiet, o - jak by się to dziś powiedziało podmiotowość kobiecą. Związana z kręgiem „Wiadomości Literackich” i skamandrytów, zapamiętana została jako przyjaciółka Boya i towarzyszka jego walk z obskurantyzmem obyczajowym, z klerykalną opresywnością.

Krzywicka z synem Andrzejem mieszkała w Bures-sur-Yvette, w domku trochę francuskim, trochę polsko-dworkowym, co w tym wypadku nie oznaczało pasów kontuszowych i karabeli na ścianach, tylko kształt architektoniczny wnętrza, z belkowanym stropem, kominkiem i przeszklonymi drzwiami do ogródka. W miejsce portretów przodków ścianę zajmowała biblioteka.

Wizyta z gatunku nieobowiązująco towarzyskich (moja siostra pracowała wówczas w tym samym co Andrzej Krzywicki Instytucie Fizyki im. Marii Curie w Orsay) splatała się z rozmową, ta zaś nie bardzo się kleiła. Polonista nie miał konwersacyjnej łączności z fizykami. Irena Krzywicka, choć trochę jej tekstów znałem, wydawała mi się postacią z kosmosu bardzo odległego, mimo że nie budziła takiego onieśmielenia jak, dajmy na to, posępny, wedle mego postrzegania, Jerzy Giedroyc. Robiło się nudno. Sytuację uratował kot, który pojawił się za szybą drzwi do ogródka i zaczął miauczeć: - Wpuść Wobicę - powiedziała Krzywicka do syna. W tym momencie olśnienie! Dość rozpaczliwie uczepiłem się wątku, który brał się z przywiązania pisarki do zwierząt domowych z przedwojennej epoki. Przypadkiem wiedziałem, skąd to imię dla kotki, jakby patronował jej wobo z rozkosznej historii o Stasiu i Nel. W krakowskim domu zachowały się numery „Wiadomości Literackich” i w jednym z nich, na pierw- 
szej kolumnie, czytałem kiedyś tekst Krzywickiej Wesele Wobicy, ilustrowany przez Zdzisława Czermańskiego. Rozmowa wreszcie potoczyła się torem interesującym dla obu stron, polonista pytał o fakty $\mathrm{z}$ historii literatury, historia literatury mogła wspominać dawne czasy. Pamiętam, że próbowaliśmy ustalić, który z dwóch wariantów fragmentu pisanego w latach wojny poematu Słonimskiego Popiót $i$ wiatr jest kanoniczny: czy ten, gdzie mowa o tym, jak ,żyła tradycja króla Ćwieczka”, o co „, kim żyła?” spytać miała „pewna aktoreczka”, czy ten, gdzie „żyła stara tradycja attycka, A z kim żyła? - spytała Irena Krzywicka”. Rozmawiało się trochę bezładnie, a trochę smutno, jak zawsze kiedy mowa o utraconym czasie, o ludziach, których nie ma, mając w tyle głowy okrutny, zwłaszcza dla świata Krzywickiej, finał tamtego, mniej więcej szczęśliwego dwudziestolecia.

Związek tego wszystkiego z Brandysem był zaś taki, że Krzywiccy, zaprzyjaźnieni od warszawskich czasów z osiadłymi niedawno w Paryżu Brandysami, przekazali mi, już po moim powrocie do Polski, przez łańcuszek pośredników wydane w „Bibliotece «Kultury»" tomy Miesięcy z dedykacjami od autora, których nie mogłem odebrać osobiście, nie spotkawszy się z nim wówczas (,krótkość czasu stała na zawadzie”...).

Natomiast wywiad z Brandysem odbył się kilka lat później, 19 września, a może z początkiem października 1989. Ze studia położonego w uliczkach Montmartre Radio „Solidarność" nadawało w języku francuskim i polskim audycje w ramach Radia Praw Człowieka. Przygotowywali je dziennikarze z krajów niezupełnie i zupełnie nie demokratycznych.

Rozmowę przeprowadziłem w towarzystwie Krzysztofa Błońskiego, dyrektorującego radiu, w mieszkaniu Brandysów przy François Miron, kilka kroków od Hôtel de Ville, ulicy równoległej do Rivoli i niedalekiej Sekwany. Długi budynek, z licowaną jasnym kamieniem fasadą. Między nią a chodnikiem, przez całą długość domu biegło kilka stopni, prowadzących do drzwi wejściowych kolejnych klatek schodowych, pomalowanych na ciemnoniebiesko i przez ten rytm barwnych plam wpadających w oko. Mieszkanie przeznaczyło miasto Paryż (merem był wtedy Jacques Chirac) dla Brandysa jako twórcy znajdującego się w szczególnej sytuacji po ogłoszeniu w kraju stanu wojennego. Poza lokalizacją mieszkanie nie wyróżniało się niczym szczególnym. Było to mieszkanko raczej. Gabinet pisarza, o ile ten studencki pokój zasługiwał na takie miano, obywał się bez biurka. Zastępował je zwyczajny drewniany blat, oparty na dwóch kozłach. Nic z tonących w książkach i antykach mieszkań — świątyń paryskich wezyrów i mandarynów literatury. Zwykła ikea za kilka franków. Na trzech deskach umocowanych do ściany rzucał się w oczy rząd „Zeszytów Literackich” (ich redakcja miała podobne do lokalu Brandysów mikroskopijne rozmiary), obok panoramiczna reprodukcja widoku dawnej Warszawy i kilka grafik.

Poza nagraniem znalazła się rozmowa o tym, co się akurat działo w Polsce. Zmieniało się wszystko - rząd, ustrój polityczny, system gospodarczy, nieprzewidywalna była nie tylko dalsza, ale i bliższa przyszłość. Brandys nie wykazywał zapału rewolucjonisty, nie przyjmował też pozy proroka, oceniającego rzeczywistość z perspektywy swego doświadczenia. Raczej inteligent w klasycznym stylu — poza niepewnymi nadziejami pełen obaw i wątpliwości. Historia zmieniała się nieraz na jego oczach szybciej niż ludzie, którzy ją tworzyli. Brandys zbyt dobrze znał demony historii, przedwojenne i powojenne również, heglowskie ukąszenia i zwyczajne rozczarowania...

Wywiad został nadany z Montmartre'u w trzech odcinkach, w okresie października i listopada 1989. Później jego fragmenty wykorzystano w audycji o Kazimierzu Brandysie przygotowanej w cyklu autorskim Krystyny Lasoń (obecnie TVN) i Włodzimierza Próchnickiego „Pisarze emigracyjni”, nadanej z krakowskiej rozgłośni Polskiego 
Radia. Powtórzyła ją w grudniu 1989 rozgłośnia warszawska. Spisaną z taśmy całość nagrania wysłałem Brandysowi, który przestylizował tekst z wypowiedzi mówionej i fragmenty zamieścił jako wstęp do wyboru Jak być kochana i inne opowiadania (Wydawnictwo Literackie, Kraków 1994). Wybór otwiera odwilżowe opowiadanie Obrona Grenady, zamyka emigracyjna Sztuka konwersacji.

Ten wstęp Od Autora, skomponowany z rozmowy paryskiej, koresponduje z wybranymi opowiadaniami. Brandys nie maluje wizji, opisując rzeczywistość, raczej ostrzega. Przypomina historyczne zaszłości, obawia się niebezpieczeństw tego, co rozgrywało się przed wojną, a może powrócić. Ten psychologiczny czy egzystencjalistyczny intymista niemal zawsze pisał o człowieku historycznym — poczynając od obrachunków inteligenckich tuż po wojnie (Miasto niepokonane, Drewniany koń), poprzez tetralogię Między wojnami, po arcydzieło - Wariacje pocztowe, opowieść o Polakach, toczącą się od osiemnastowiecznych klęsk, po lata 60. XX wieku. Wśród konfabulacji i mitów, buntów jednostek uwięzionych w sidłach zbiorowego szaleństwa, rwących bezustannie nitki indywidualnego bytu i kręcących mozolnie sznur romantycznych majaków, egzorcyzmujących oświeceniowego samobójcę, niewyzwolonych z zacieków sarmackich...

O jakich konwulsjach historii, niewczesnych zamiarach, o jakich swarach myślał jesienią 1989 roku Kazimierz Brandys, nagrywając tę rozmowę na kasetowym magnetofonie, w pięknym mieście Paryżu? 